Calcutta, for his valuable co-operation, help and advice in carrying out this piece of research. We also tender our grateful thanks to Dr. P. K. Biswas, of the Eye Infirmary, Medical College Hospitals, Calcutta, for many services.

\title{
REPERENCES
}

BALDES, E. T. (1934)-Journal Scientific Instruments, Vol. XI, July.

Baurman. (1928)-Ber. Ophthal. Ges., Heidelberg. Vol. XLVII, pp. 157-221.

Chopra, R. N., and DE. N. (1937)-Indian Jl. Med. Research, Vol. XXV, p. 101. Duke-Elder, W. S., Davson and BenhaM. (1936)-Brit. Jl. of Ophthal., Vol. XX. p. 520.

DUKE-ELDER, W. S. (1927)-Biochem. Jl., Vol. XXI, p. 66.

- (1934)-Physiol. Rev., Vol. XIV.

(1936)-Biochem. Jl., Vol. XXX, p. 773.

- (1937)-Brit. Jl. of Ophthal., Vol. XXI, p. 377.

Hill, A. V. (1930)-Proc. Roy. Soc., Series A, Vol. CXXVII, p. 9.

KIRWAN, E.O'G. (1934)-Arch. of Ophthal., Vol. XII, July.

(1936)-Brit. Jl. of Ophthal.. June, p. 321.

Mestrezat and Magitot. (1921)-Comp. rend. Soc. Biol., Vol. LXXXIV, p. 185.

\section{STUDIES ON THE PATHOGENY OF TRACHOMA*}

\author{
BY \\ L. A. Julianelle \\ OSCAR JOHNSON.INSTITUTE WASHINGTON UNIVERSITY SCHOOL \\ OF MEDICINE, ST. LOUIS, MISSOURI
}

DURING the course of studies pursued in this laboratory for the past six years on the aetiological relationships of trachoma, certain facts have been revealed which reflect the nature of the causative agent of this disease. It appears desirable at this time to bring together these facts in the manner of a recapitulation in order to construct a pattern of the pathogeny of trachoma.

In the work conducted thus far, it has been demonstrated, as others showed before us ${ }^{1}$, that material derived from the conjunctiva of patients with trachoma, while completely innocuous for dogs, rabbits, hogs, guinea-pigs, rats, and mice, induces on the conjunctiva of monkeys an infection characterised essentially by folliculosis ${ }^{2}$. Preceded by an incubation period of several days to a month, the experimental disease frequently extends from the inoculated to the uninoculated eye and endures for a few weeks to many months, in some instances two and three years. The histological changes, although simulating those in trachoma, are

* Read at the XV International Congress of Ophthalmology, Cairo, December 10, 1937. Conducted under a grant from the Commonwealth Fund of New York. 
not emphasised, because follicular reactions of the conjunctiva in general lack any features distinguishing the one from the other. Inoculation of trachomatous material in tissues other than the conjunctiva was found to be without effect. Tissues from different patients vary greatly in infective capacity, and despite the caution exercised in selecting only recent and clinically active disease, about half the tissues only are infectious. Conversely, individual animals (Macacus rhesus) exhibit a marked difference in susceptibility, approximately half the monkeys being resistant. It has not been possible to adapt the infection permanently in monkeys, since usually by the third serial passage the infectious agent is $\epsilon$ ither lost or completely inactivated. Upon recovery, no resistance to infection or immunity to the experimental disease is demonstrable. Up to the present time, a hundred or more infected animals have been examined for the epithelial cell inclusions frequrntly observed in human beings, but neither scrape smears nor histological sections have revealed their presence.

Since the experimental disease lacks the two distinguishing signs of spontaneous trachoma (i.e., cicatrization and pannus), experiments were performed ${ }^{3}$ to indicate by virtue of its specificity the genuineness of the disease. Thus, human folliculosis, which in appearance may resemble the experimental disease, is not transmissible to monkeys; the formation of follicles is not stimulated by non-specific infection with a variety of bacteria, by irritation or by auto-inoculation of follicles occurring spontaneously in certain monkeys.

Experiments devised to elucidate the effect of faulty diet on the experimental disease ${ }^{4}$ consisted of inoculating monkeys maintained on the diets deficient in vitamin $\mathrm{A}$, or inadequate qualitatively and quantitatively in protein, or inadequate in protein and high in fat, or high in fat. The data indicate clearly that a state of malnutrition, as described with its resultant debilitation, does not predispose monkeys to trachoma ; on the contrary, the animals appear to be less reactive than those maintained on an adequate diet.

Subsequently, in attempting to define the infectious agent of trachoma, an elaborate study was made of the bacteria cultivable from the disease. A number of workers have ascribed the causation of trachoma to different specific organisms ${ }^{5}$, while other authors failed to find any characteristic bacteria ${ }^{6}$. It was found in this laboratory ${ }^{7}$ that trachoma is not characterised by any particular flora, since the same bacteria may be isolated in similar frequency from other conditions of the eye, and to a less extent even from normal eyes. The-variety of bacteria is extensive, and it remains unchanged in the different stages of the uncomplicated disease and is unrelated to the presence of inclusions. Inoculation 
of the bacteria cultivated, either individually, pooled, or in conjunction with Berkefeld filtrates of infectious material, is without effect on monkeys, even though the tissues from which they are derived are of demonstrable specific infectivity.

The question of whether the infectious agent of trachoma is filterable has occupied the attention of previous workers. Some have succeeded ${ }^{8}$ in transmitting trachoma with bacteriologically sterile fitrates, while others found such filtrates to be inactive $e^{3}$. In any case, however, the number of experiments conducted by the majority of the workers has been too small to include the different variables present in tissue infectivity and animal resistance. Filterability of the infectious agent was also studied in this laboratory by filtration through Berkefeld $V$ filters. Of 14 experiments performed ${ }^{10}$, the original material was infectious in 11. Filtrates of these tissues failed to infect monkeys of demonstrated susceptibility in 10 experiments, and in one the filtrate was as actively infectious as the material from which it was obtained.

Subsequently, the subject of filterability was restudied ${ }^{11}$ to include variables in the process of filtration which might possibly interfere with the ready passage of the agent. Filtration of the infectious agent was attempted through Berkefeld V, collodion (average pore diameter about 0.6 $\mu$ ), Seitz, and Kramer (plaster of Paris) filters. In seven experiments with material of demonstrated infectivity, filtration conducted in parallel with all four filters, filtrates were infectious only twice, and in each instance the agent traversed only the Berkefeld filter. In one of these two experiments, a collodion membrane (A.P.D. $0.93 \mu$ ), pervious to $B$. prodigiosus, was impervious to the trachomatous agent. In five other trials, collodion membranes alone were employed and their corresponding filtrates were deprived of the infectivity of the original materials. Thus, then, a total of 23 experiments have been undertaken during the two studies, and the infectious agent of trachoma was found to be filterable on three occasions. The evidence indicates, therefore, that bacteriologically sterile filtrates of human trachomatous tissues may retain their originally infective capacities. The infectious agent, however, is irregularly filterable and the difficulties of successful filtration may be attributable to variations both in the infectious tissues themselves and in the composition of the filter employed for the purpose.

The studies thus far reviewed suggest that the causative agent of trachoma is a virus. In order to obtain further evidence of its nature, adaptation was made of passing trachomatous tissues through rabbit testicle ${ }^{12}$. By such passage, the causative agent is liberated of extraneous bacteria and may be recovered in an active or infective condition (in 11 of 27 experiments). The absence during passage of any reaction, clinical or histological, 
in the testicular tissue, the inability of the infectious agent to survive serial passage, and the maintenance of infectivity following recovery at approximately the original potency, all indicate that the causative agent does not multiply in the testicle but is merely preserved. Survivability in testicular tissue is not related with the presence of observable elementary or initial bodies in the original material nor with the formation of these structures in the testicle. Other experiments disclosed that successful passage of the agent may be accomplished occasionally by cerebral passage in rabbits, in which case no specific tissue reaction accompanies the successful passage.

The results already described in connection with testicular passage reveal the inability of the infectious agent of trachoma to multiply in the usual bacteriological media. A study was made, therefore, of cultivability in tissue cultures ${ }^{13}$. For this purpose, the technique devised by Maitland and Maitland of minced rabbit kidney ${ }^{14}$, and as modified by Li and Rivers ${ }^{15}$ of minced chick embryo, the developing chick egg (Woodruff and (ioodpasture ${ }^{16}$; also Burnet and Galloway ${ }^{17}$ ), and various tissue fragments in plasma, were particularly utilised. In order to control both the methods and conditions of growth, similar experiments were carried out with the virus of St. Louis encephalitis, as already reported ${ }^{18}$. These methods of tissue cultivation were supplemented later by cultures made in plasma clots with human placental tissue extract and plasma from patients or normal individuals. In attempting to approximate very closely the conditions found in the eye, epithelial cells containing both the infectious agent (as demonstrated by inoculation of monkeys), and in some cases even inclusion bodies, were seeded by this method.

The technical difficulties accompanying the studies in tissue cultivation were numerous, the most consistent being the presence of adventitious bacteria in the original tissues. In the earlier seedings they were almost always present in the inocula, and they grew rapidly in culture, with the result that the growing cells were quickly destroyed or suppressed, thus defeating the purpose of the experiment. The use of several methods and chemicals, to inactivate selectively the bacteria only, was of no avail, since the infectious agent proved to be less resistant to the different substances. This obstacle was circumvented, however, by careful irrigation of the eye with salt solution, and then making multiple seedings of essentially epithelial scrapings collected in Tyrode's solution. While it was not possible to eliminate bacterial growth entirely in this way, bacteriologically sterile tissue cultures were frequently obtained. The seeded cultures were incubated both at $30^{\circ}$ or $32^{\circ} \mathrm{C}$. (to approximate the temperature of the conjunctiva) 
and at $35^{\circ}$ or $3 \pi^{\circ} \mathrm{C}$., and incubation was carried out for three to seven days before transplants were made or before the cultures were nourished. Other cultures, under similar conditions, were made from infected eyes of monkeys and from testicular tissue carrying the infectious agent. In testing for infectivity, tissue cultures were inoculated in monkeys before and after transplanting and in every case the inoculum was derived from several cultures which had been pooled and triturated.

In summary, then, a total of 1,175 tissue cultures were made by cultivating and inoculating tissue from different animal species in 81 experiments, in 31 of which the original human material was infectious for monkeys. From 30 to 40 per cent. of the trachomatous materials employed in the different experiments on cultivation were found to contain epithelial cell inclusions. In none of the cultures, however, was it possible to demonstrate the presence of either constituent of the inclusion or the infectious agent of trachoma by inoculation of monkeys.

Cultivations attempted on a lesser scale in minced mouse kidney, in guinea-pig testicle, in the Brown-Pearce tumour of rabbits, in testicle and conjunctiva of monkeys, were all uniformly negative. In several instances, infectious material was inoculated in rabbit testicle simultaneously with a ground suspension of the rabbit tumour described by Brown and Pearce. Again the results indicate a failure of the infectious agent to grow. At other times, tissue cultivation was carried out anaerobically, as suggested by Dochez, Mills, and Kneeland ${ }^{19}$, without, however, affecting the results already observed with other techniques. A few other experiments were attempted with cultivation of human placenta, but these were discontinued because of the difficulties encountered in growing this tissue.

The evidence is clear, then, that despite numerous attempts to cultivate the infectious agent of trachoma under a variety of conditions, in tissues from six different animal species, including man, and a cultivable rabbit tumour, it has not been possible to create in vitro the proper conditions for multiplication. While successful cultivation of the trachomatous agent in the fertile egg had been reported in a preliminary communication from India ${ }^{20}$, a subsequent report ${ }^{21}$ indicates that the original criterion of propagation was due to technical misinterpretations. More recently Poleff'2 has reported successful cultivation of the infectious agent by the Carrel technique and he identifies the agent as the inclusion body.

Experiments were subsequently conducted ${ }^{23}$ to determine the susceptibility of the infectious agent to different chemical and physical agents. Recognising the danger of generalisation, since the variation both in infectivity of tissues and in susceptibility of 
animals is great, it nevertheless seems fair to depict the characteristics to be described as typical of the infectious agent of trachoma. It is inactivated by heating at $45^{\circ}$ to $50^{\circ} \mathrm{C}$. for 15 minutes; it is rendered non-infectious by the action of ox-bile which causes lysis of epithelial cells and inclusions; it does not survive exposure to dilutions of $1 \cdot 100,000$ gentian violet, 0.25 per cent. phenol, 2 per cent. silver nitrate, 4 per cent. cocaine, and in about half the tissues tested even 2 per cent. cocaine, and tartar emetic in concentration of $1 \cdot 1,000$ is also destructive.

Preservation of the infectious agent of trachoma in glycerine has been reported by several workers, with a remarkable difference of opinion ${ }^{24}$. In most cases, however, the data are difficult of analysis, since little effort was made to determine either the original infectivity of the material or preservation under the same conditions without glycerine. In these experiments, the infectivity of the original suspensions was tested, and when they were found to be non-infectious, the data were discarded. The results of repeated experiments indicate that at ice box temperature glycerine does not maintain the infectious agent active any longer than preservation without glycerine. Ordinary preservation at this temperature varies, with different suspensions, from one or two days to a week or more. In general, however, tissues lose their activity within three or four days under these conditions.

The common clinical history of repeated infection in patients with trachoma was experienced in the experimental work when it was shown that monkeys acquire no active immunity to infection after recovery from the artificially induced disease. Nevertheless, an effort was made to determine whether human sera may act to prevent or diminish experimental infection. Conjunctival scrapings from patients, of verified infectivity, were mixed under different conditions of incubation with sera, whole blood, or plasma, derived in some experiments from the patients themselves, and in others from normal individuals. The results of these experiments indicate that blood from patients with trachoma contains no demonstrable substance capable of inactivating or neutralising the infectious agent, as measured by the development of experimental trachoma in monkeys.

\section{Discussion}

The accumulated studies on the aetiology of trachoma by numerous workers as well as ourselves no longer permit a reasonable rejection of the evidence that the disease is an infection in its own right without benefit of associated factors such as constitution, nutrition, co-related infection, etc. The exact nature of the infectious agent, however, has been in doubt for a long time, 
but it is rapidly becoming more clearly visualised as a result of the more recent investigations. At the present time, the indications are that the agent is not a bacterium but a virus.

There are several reasons for considering the aetiological agent to be a virus. Most impressive, perhaps, is its inability to multiply on a number of bacteriological media, as well as in the more delicate environment of tissue culture. Occasionally by filtration, and more frequently by testicular passage, it may be liberated of any cultivable or visible forms and still retain its original infectivity. The exquisite tissue specialisation, species specificity, inclusion body formation, etc., are all added evidence of the viral nature of the infectious agent.

A recent development by Busacca ${ }^{25}$, Cuenod ${ }^{26}$, and Poleff ${ }^{27}$ portrays the causative agent as a rickettsia, the most favourable evidence being the observation from Cuenod's laboratory ${ }^{28}$ that inoculations of ground lice containing rickettsiae derived from trachoma may induce experimental trachoma in both monkey and man. By means of tissue culture, Poleff'2 identifies the rickettsial form as a component of the inclusion body first described by Halberstaedter and Prowazek and designated by them as the cause of trachoma. If, then, the rickettsial forms are indeed associated with the epithelial cell inclusion, the question of aetiology becomes less involved, as will be brought out presently.

While the inclusion body has been incriminated repeatedly in the past as the causative agent of trachoma, it remained for Thygeson, Proctor and Richards ${ }^{29}$ to bring forward the weightiest argument in favour of this relationship. It will be recalled that in their hands a bacteriologically sterile filtrate of human trachomatous tissues was obtained with a collodion membrane impervious to Bact. granulosis and H. influenzae, that typical elementary bodies were found in the filtrate, and that the filtrate induced genuine trachoma in a human volunteer, as well as unmistakable inclusion bodies.

The question remains, then, whether the virus of trachoma is synonymous with the inclusion body or its component elements. This is, indeed a more fundamental question than trachoma, since it seeks the answer of a more general query perpetually raised by students of viruses regarding the identity or lack of identity of viruses and inclusions and without as yet a conclusive response.

It is beginning to appear, however, that viruses and inclusions may be, indeed, the same thing ${ }^{30}$.

Consequently, by way of summary and conclusion, it may be said that the infectious agent of trachoma is characterised by low infectivity, occasional filterability, marked tissue specialisation, ineffectual immunogenic properties, slight propagative capacity, sensitivity to physical and chemical agents, and the 
accompaniment of inclusion bodies. All these properties suggest the probability that the infectious agent is a virus. Whether the virus may be defined in turn as the inclusion body or its component elements remains to be proved, although the evidence available at the present time suggests this may be actually the case; whether again the inclusion body may be defined further as a rickettsia must also await upon future investigation. In the meantime, the three concepts of virus, inclusion body, and rickettsia are not so divergent as they appear at first glance; what differences each appears to have from the others are of the order less of fact and more of definition and classification.

\section{BIBLIOGRAPHY}

It would be impossible in a report of this kind to attempt more than a cursory reference to the extensive literature bearing on the various aspects of the aetiology of trachoma. A thorough review of the literature, with a more or less complete bibliography, will be found in a forthcoming monograph now in the press on the aetiology of trachoma, to be published by the Commonwealth Fund Division of Publications of New York.

1. Hess, C., and Römer, P.-Arch. f. Augenheilk., Vol. LV, p. 1, 1906. HALBERSTÄTER, L., and PROWAzEK, S.-Deutsch. med. Wochenschr., Vol. XXXIII, p. 1285, 1907. HERFORD, E.-Klin. Monats. f. Augenheilk., Vol. XLVII, p. 225, 1909. Morax, W.-Ann. d'ocul., Paris, Vol. CXLV, p. 414, 1911. HeYman, B.-Klin. Monats. f. Augenheilk., Vol. XliX, p. 417, 1911. Nicolle, C., Cú́nod, A., and Blaizot, L.-Arch. Inst. Pasteur Tunis, Vol. III, p. 185, 1911. AdDARIO, LA FERLA. - Ann. d'ottal., Pavia, Vol. XIV, p. 278, 1912. OLITSKY, P. K., and TYLER, J. R.-Science, Vol. LXXI, p. 564, 1930 ; Jl. Exp. Med., Vol. LIV, p. 31, 1931.

2. Julianelle, L A., and Harrison, R. W.-Amer. Jl. Ophthal., St. Louis, Vol. XVI, p. 867,1933 ; Vol. XVII, p. 1035, 1934.

3. Amer. Jl. Ophthal., St. Louis, Vol. XVIII, p. 11, 1935.

4. Hetler, R. A., and James, W. M.-Amer. Jl. Ophthal., St. Louis, Vol. XVII, p. 1048, 1934.

5. Sattler, H.-Ber. Versamml. ophthal. Ges., Vol. XIII. p. 18, 1881. Косн, R.-Wien. klin. Wochenschr., Vol. XXXIII, p. 1550, 1883. M ICHEL, J.-Arch.f. Augenheilk., Vol. XVI, p. 348, 1885. MÜLLER, L.-Wien. klin. Wochenschr., Vol. X, p. 920, 1897; Arch. f. Augenheilk., Vol. XI, p. 13, 1900. RAEHLMAN, E.-Beitr. z. Augenheilk., Vol. ViI, p. 35, 1908. Edwards, P. T.-Jl. Amer. Med. Assoc., Vol. XLIV, p. 965, 1910. Williams, A. W.-Arch: of Ophthal., New York, Vol. XLII, p. 506, 1913. NoguCHi, H.-Jl. Exp. Med., Vol. XLVIII, suppl. 2, 1928. Lumbroso, U.-Arch. Inst. Pasteur Tunis, Vol. XX, p. $253,1931$.

6. Cazalis, C. A.-Trachome, Thèse de Montpellier, 1896. LAwson, A.Roy. Lond. Ophthal. Hosp. Rep., Vol. XIV, p. 484, 1897. Uнthoff. W.-Zentrl. prakt. Augenheilk., Vol. XXII, p. 357, 1898. WAKIZAKA, K.-Klin. Monats. f. Augenheilk., Vol. XLVII, p. 793, 1909. PACALIN, G.-Arch. d'Ophtal., Paris, Vol. XLVII, p 690, 1930. SEIDLER, M., and Stasinska, J - Klin. Monats. f. Augenheilk., Vol. LXXXVI, p. 261, 1931. TABORISKY, J.-Folia ophthal. orient., Vol. I, p. 34, 1932. ThYGESON, P.-Arch. Inst. Pasteur Tunis, Vol. XXII, p. 157, 1933.

7. Harrison, R. W., and Julianelle, L. A.-Amer. Jl. Ophthal., St. Louis, Vol. XIX, p. 118, 1936. 
8. Bertarelli, E,, and Cechetto, E.-Centr. Bakt., I. Abt., Orig., Vol. XLVII, p. 432, 1908. MarongIU, L.-Policlinico, sez. prat., Rome, Vol. XV, p. 805, 1908. Nicolle, C., Cuenod, A., and Blaizot. L.Compt. rend. Acad., Vol. CLV, p. 214, 1912. Olitsky, P. K., KNUtti, R. E., and TYLER, J. R.-Jl. Exp. Med., Vol. LIV, p. 557, 1931.

9. Pfeiffer, R., and KunNT, H.-Zeitschr. f. Augenheilk., Vol. XIII, p. 321, 1905. HESS, C., and RömER, P.-Arch.f.Augenheilk., Vol. LV, p. 1, 1906. BAIARDI, P.-Clin. ocul., Vol. VIII, p. 2719, 1907. FERMI, C., and RePetto, R.-Berl. klin. Wochenschr., Vol. XLIV, p. 1197, 1907. SzAFNICKI.-Zentrl. ges. Ophthal., Vol. XXI, p. 45, 1929. TRAPESONTZEWA, C.-Rev. internat. trachome, Vol. VII, p. 65, 1930. Lumbroso, U., and Thygeson, P.-Arch. Inst. Pasteur Tunis, Vol. XXII, p. 178, 1933. STEWART, F. H.-Ann. Rep. Giza Mem. Ophthal. Lab., Vol. VIII, p. 142, 1933. CANdian, F. L.-Atenca Parmense, Vol V, p. 224, 1933. WRIGHT, R. E.-Brit. Jl. Ophthal., Vol. XXI, p. $198,1937$.

10. Julianelle, L. A., and Harrison, R. W.-Amer. Jl. Ophthal., St. Louis, Vol. XVIII, p. 133, 1935,

11. Morris, M. C., and Harrison, R. W.-Amer. Jl. Ophthal., 1937 (in press).

12. and HARRISON, R. W.-Trans. Amer. Acad. Ophthal. and Otol., p. 221, 1935 ; also Amer. Jl. Ophthal., St. Louis, Vol. XX, p. 353, 1937.

13. Harrison, R. W., and Julianelle, L. A.-Amer. Jl. Ophthal., Vol. XX, p. $360,1937$.

14. Maitland, H. B., and Maitland, M. C.-Lancet, Vol. II, p. 596, 1928.

15. Li, C. P., and Rivers, T. M.-Jl. Exp. Med., Vol. LII, p. 465, 1930.

16. Woodruff, A. M., and Goodpasture, E. W.-Amer. Jl. Path., Vol. VII, p. $209,1931$.

17. Burnet, F. M., and Galloway, I. A.-Brit. Jl. Exp. Path., Vol. XV, p. $105,1934$.

18. Harrison, R. W., and Moore, E.-Proc. Soc. Exp. Biol. and Med., Vol. XXXV, p. 359, 1936.

19. Dochez, A. R., Mills, K. C., and KNeELAND, Y., Jr.-Jl. Exp. Med., Vol. LXIII, p. 559, 1936.

20. PANDit, C. G., Wright, R. E., RaO, R. S., and Satyanathan.-Indian $J l$. Med. Res., Vol. XXIII, p. 475, 1935.

21. Wright, R. E.-Brit. Jl. Ophthal., Vol. XXI, 198, 1937.

22. PolefF, L.-Rev. internat. trachome, Vol. XIII, p. 153, 1936 ; also Arch. d'Ophtal., Paris, Vol. LIII, p. 882, 1936.

23. Julianelle, L. A., Harrison, R. W., and Morris, M. C.-Jl. Exp. Med., Vol. LXV, p. 735, 1937.

24. Nicolle, C., Cuenod, A., and Blaizot, L.-Arch. Inst. Pasteur Tunis, Vols. III and IV, p. 157, 1913. BARONI, V., and MICHAIL, D.-Rev. internat. trachome, Vol. IX, p. 31, 1932. CANDIAN, F. L.-Ann. ottal., Pavia, Vol. LXI, p. 890, 1933. STEWART, F. H.-Ann. Rep. Giza Mem. Ophthal. Lab., Vol. VIII, p. 142, 1933 ; Vol. IX, p. 95, 1934. BusAccA, A.-Folia clin. biol., Vol. VII, p. 63, 1935.

25. Busacca, A.-Folia clin. biol., Sao Paulo, Vol. V, p. 96, 1933 : also Arch. f. Ophthal., Leipsig, Vol. CXXXIII, p. 41, 1934.

26. Cuenod, A.-Arch. d'Ophtal., Paris, Vol, LII, p. 145, 1935 ; also Rev. internat. trachome, Vol. XIII, p. 9, 1936.

27. PolEFF, L.-Rev. internat. trachome, Vol. XIII, p. 153, 1936.

28. Cuenod, A., and Nataf, R.-Brit.Jl. Ophthal., Vol. XXI, p. 309. 1937.

29. Thygeson, P., Proctor, F. I., and RichaRds, P.-Amer. Jl. Ophthal., St. Louis, Vol. XVIII, p. 811,1935 ; also Arch. of Ophthal., New York, Vol. XIII, p. 1018, 1935.

30. Barnard, J. E., and ElFord, W. J -Proc. Roy. Soc. Lond., Series B. Vol. CIX, p. 360, 1931-32. BEDSON, S. P., and BLAND, J. O. W.Brit. Jl. Exp. Path., Vol. XV, p. 243, 1934. LEDINGHAM, J. C. G.Lancet, Vol. II, p. 525, 1931. PARKer, R. E., and RIVERS, T. M.Jl. Exp. Med., Vol. LXIV, p. 439, 1936. WoodRUFF, C. E., and Goodpasture, E. W.-Amer. Jl. Path. Vol. V, p. 1, 1929; also Vol. VI, p. 712, 1930. 